\title{
WPŁYW ZMIAN REGULACJI PRAWNYCH NA REALIZACJĘ BUDOWLANEGO PROCESU INWESTYCYJNEGO
}

\author{
Iwona Rybka ${ }^{\bowtie}$, Elżbieta Bondar-Nowakowska \\ Wydział Inżynierii Kształtowania Środowiska i Geodezji, Uniwersytet Przyrodniczy we Wrocławiu, Wrocław
}

\begin{abstract}
STRESZCZENIE
W pracy przedstawiono problem zmian przepisów prawnych w odniesieniu do budowlanego procesu inwestycyjnego. Wprowadzane w ostatnich latach zmiany prawne dotyczą wszystkich etapów i obszarów tego procesu, szczególnie zaś zakresu prawno-administracyjnego. Mogą one przyczynić się do zakłócenia działań realizowanych przez wszystkich uczestników przedsięwzięcia budowlanego. Przeprowadzone badania wykazały, że następstwem zmian przepisów może być wzrost kosztów realizacji inwestycji. Ze względu na losowy charakter takich zdarzeń potrzebne jest zarządzanie ryzykiem zmian przepisów prawnych w procesie budowlanym.
\end{abstract}

Słowa kluczowe: przepisy prawne, budowlany proces inwestycyjny, ryzyko

\section{WSTĘP}

Cechą charakterystyczną polskiego systemu prawnego są częste zmiany w przepisach. W ostatnich latach wskaźnik zmienności prawa jest szczególnie wysoki. W 2014 roku w Dzienniku Ustaw opublikowano 1995 aktów prawnych, a w 2015 roku - 2375. Tak duża liczba wynika m.in. z potrzeby dostosowania polskiego prawa do wymogów Unii Europejskiej, nadmiernej polityki legislacyjnej oraz poprawiania wadliwych przepisów (Grant Thornton, 2016). Problem zmienności prawa dotyczy również budownictwa, gdyż budowlany proces inwestycyjny regulowany jest szeregiem aktów prawnych. Normują one m.in. zagadnienia związane z planowaniem, projektowaniem oraz realizacją obiektów budowlanych (Olszewski, 2011). Na każdym etapie procesu inwestycyjnego konieczne jest opracowanie wielu dokumentów, złożenie stosownych wniosków, operatów czy ekspertyz zgodnie z wymaganiami prawa. W związku z tym każda zmiana obowiązujących przepisów bądź wprowadzenie nowej regulacji prawnej może mieć wpływ na przebieg procesu budowlanego (Korycki, Kuciński i Trzciński, 2007; Błachut, Rybka, Rybka i Sługocki, 2013; Głuszak i Leśniak, 2015).

Jedną ze specyficznych cech przedsięwzięć budowlanych jest długi czas ich trwania. Oznacza to, że warunki przyjęte w momencie ich planowania mogą różnić się od tych występujących w kolejnych etapach procesu inwestycyjnego. Dla zarządzających przedsięwzięciem budowlanym może to być czynnik zagrażający spełnieniu przyjętych zobowiązań. W związku z tym potrzebne jest zarządzanie ryzykiem zmian regulacji prawnych (Kuziak, 2008).

Celem niniejszej pracy jest rozpoznanie czynników tego ryzyka. Istnieje bowiem zasada, że aby skutecznie zarządzać ryzykiem, trzeba je najpierw zmierzyć (Ostrowska, 2002).

凶iwona.rybka@up.wroc.pl 


\section{MATERIAt I METODY}

Na podstawie przeglądu przepisów prawnych w Internetowym Systemie Aktów Prawnych (ISAP 2016) wyróżniono obszary prawnie regulowane $\mathrm{w}$ procesie budowlanym. Wyniki tej analizy przedstawiono $\mathrm{w}$ formie diagramu Ishikawy. Następnie określono skalę problemu zmian w prawie. Podstawę tego działania stanowiła analiza zmian aktów prawnych opublikowanych w Dzienniku Ustaw w latach 2015-2016 (Dziennik Ustaw, 2016). W analizie rozpatrywano tylko te przepisy, których skutek nastąpił w 2016 roku. Było ich 40 . Z uwagi na to, że część ustaw dotyczyła opublikowania tekstów jednolitych, w drugim kroku przeprowadzono selekcję rozpatrywanego materiału. Ostatecznie wybrano 25 aktów, których postanowienia dotyczyły procesu budowlanego. Wybrane ustawy i rozporządzenia sklasyfikowano według etapu oraz obszaru ich oddziaływania w procesie inwestycyjnym.

W celu oszacowania wpływu zmian prawnych na realizację procesu budowlanego przeprowadzono badania ankietowe. Ankieta miała charakter ekspercki. Wybór ekspertów został dokonany na podstawie dwóch kryteriów. Pierwsze kryterium zakładało, by osoba wytypowana do badań posiadała minimum 5-letni staż zawodowy. Drugie kryterium stanowiło, by ekspert uczestniczył w przedsięwzięciach budowlanych, wykonując pracę na stanowisku kierowniczym. Powyższe kryteria spełniło 51 osób. W ankiecie respondenci odpowiedzieli na pytania:

- czy podczas realizacji danego przedsięwzięcia budowlanego wystapiły zmiany prawa i/lub niespójne zapisy prawne?

- jaki był skutek wprowadzonych zmian prawnych?

\section{WYNIKI I DYSKUSJA}

Na podstawie przeglądu aktów prawnych wyróżniono trzy obszary oddziaływania przepisów prawa w procesie inwestycyjnym. Obszary te są powiązane wymaganiami technicznymi, prawnymi i administracyjnymi oraz odnoszą się do uczestników procesu budowlanego. $Z$ rysunku 1 wynika, że w celu zidentyfikowania ryzyka zmian przepisów prawnych potrzebna jest doskonała wiedza na temat organizacji procesu we wszystkich jego obszarach oraz na wszystkich jego etapach.

W kolejnym etapie badań wyodrębniono akty prawne opublikowane w latach 2015-2016, których postanowienia zmieniały warunki realizacji procesu budowlanego. $\mathrm{W}$ dokonanym przeglądzie określono etap procesu inwestycyjnego oraz obszar wpływu, których dotyczy zmiana w prawie. Dane te przedstawiono w tabeli 1.

Przedstawione dane wskazują, że w rozpatrywanym okresie najwięcej zmian w przepisach dotyczyło zagadnień związanych z wymaganiami prawnymi i administracyjnymi. Z tym obszarem procesu inwestycyjnego związanych było 16 aktów. Dokonane zmiany regulacji prawnych odnosiły się najczęściej do etapu projektowania (11 aktów) oraz etapu robót budowlanych (10 aktów). W przypadku projektowania dotyczyły głównie przygotowania dokumentacji projektowej. $Z$ punktu widzenia inwestora precyzowały m.in. wymagania, jakie musi on spełnić, aby otrzymać decyzję o pozwoleniu na budowę lub rozbiórkę. Podobnie jak w przypadku projektowania, na etapie wykonywania robót zmiany prawne w większym stopniu dotyczyły procedur administracyjnych niż rozwiązań i działań technicznych.

Z wykazu przedstawionego w tabeli 1 wynika, że prawdopodobieństwo zmian przepisów prawnych w trakcie realizacji robót budowlanych jest duże. W ocenie ryzyka, oprócz ustalenia prawdopodobieństwa wystapienia zakłóceń, równie ważne jest wyznaczenie ich skutków w określonej perspektywie (Bizon-Górecka i Górecki, 2015). W rozpatrywanym rodzaju ryzyka trudniejszy w ocenie jest ten właśnie czynnik - skutki zmian przepisów prawa. Z uwagi na brak danych statystycznych w celu oszacowania skali tego problemu wykorzystano wyniki przeprowadzonej ankiety. Eksperci, którzy wskazali, że podczas realizowanego przez nich przedsięwzięcia budowlanego wystąpiły zmiany przepisów prawa, stwierdzili równocześnie, że następstwem tych zmian było: 
Rybka, I. i Bondar-Nowakowska, E. (2017). Wpływ zmian regulacji prawnych na realizację budowlanego procesu inwestycyjnego. Acta Sci. Pol. Architectura, 16 (2), 39-45. doi: 10.22630/ASPA.2017.16.2.05.

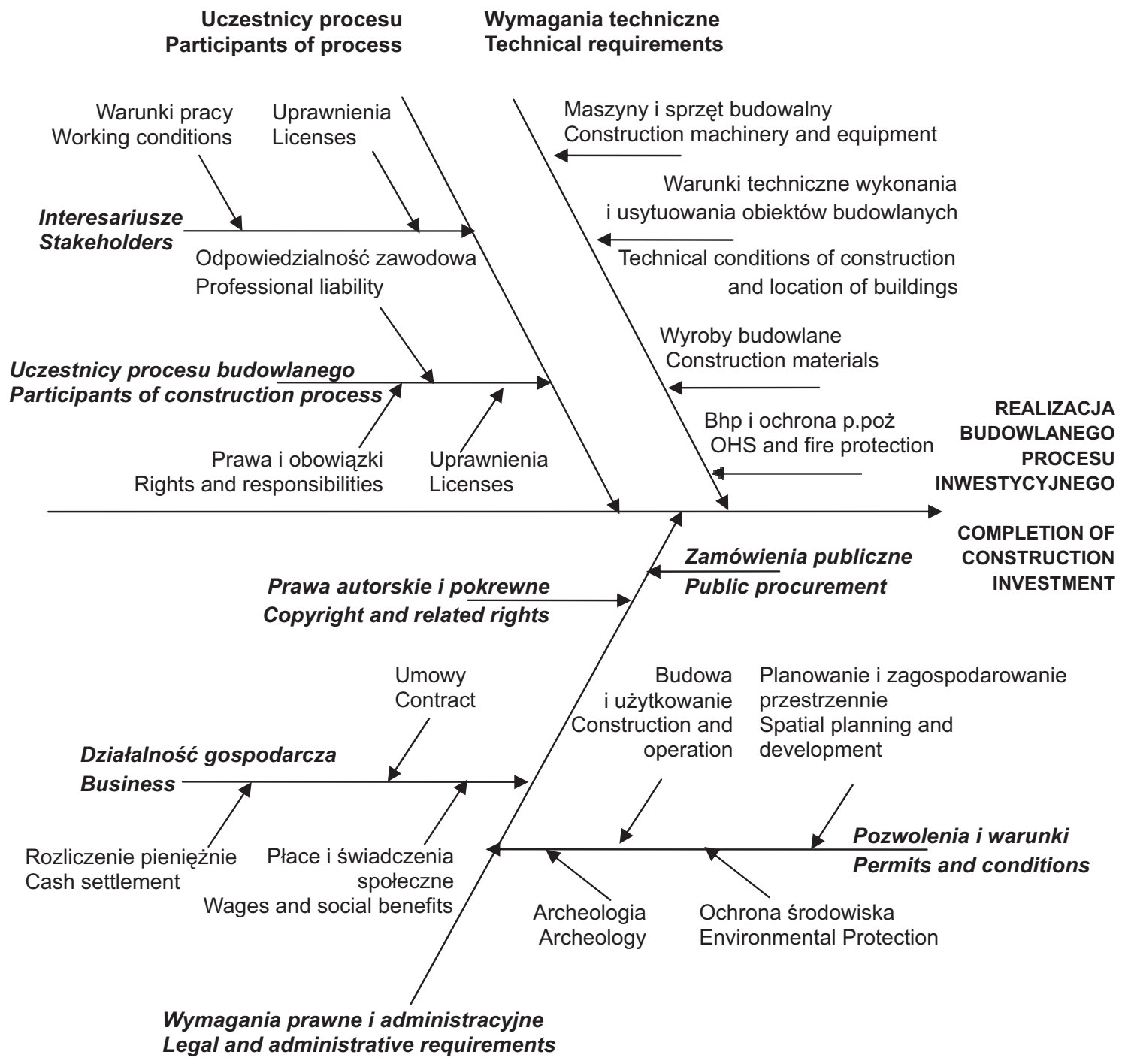

Rys. 1. Obszary oddziaływania regulacji prawnych na realizację budowlanego procesu inwestycyjnego (opracowanie własne)

Fig. 1. The areas of impact of legal regulations on completion of construction investment process (authors`own elaboration)

zwiększenie całkowitego kosztu inwestycji, zwiększenie całkowitego kosztu inwestycji i równocześnie opóźnienie terminu zakończenia inwestycji, a także konieczność modyfikacji zaplanowanych działań (pozostałe). Ostania grupa następstw to przypadki, w których ankietowane osoby dostrzegły, podczas realizowanych przez nich kontraktów zmianę przepisów prawa, lecz stwierdziły, że nie wpłynęły one na zwiększenie kosztu bądź wydłużenie czasu inwestycji. Przykładem tego może być wymóg złożenia wniosku na innym niż dotychczas obowiązującym formularzu lub przekazania go do innego organu. Zmiany takie należy traktować jako niedogodność, która nie ma wpływu na efekt końcowy inwestycji. Procentowy podział przedstawionych następstw przedstawiono na rysunku 2. 
Tabela 1. Zmiany regulacji prawnych $w$ latach 2015-2016, związanych z budowlanym procesem inwestycyjnym (opracowanie własne)

Table 1. Changes in legal regulations related to the construction investment process between 2015 and 2016 (authors` own elaboration)

\begin{tabular}{|c|c|c|c|}
\hline Lp. & Akt prawny & $\begin{array}{c}\text { Etap procesu } \\
\text { inwestycyjnego }\end{array}$ & Obszar wpływu \\
\hline No & Legal regulation & $\begin{array}{c}\text { Stage of the } \\
\text { investment process }\end{array}$ & Area of influence \\
\hline
\end{tabular}

1 Ustawa z dnia 9 października 2015 r. o związkach metropolitalnych

Ustawa z dnia 16 grudnia 2015 r. o zmianie ustawy - Prawo wodne oraz ustawy o zmianie ustawy - Prawo wodne oraz niektórych innych ustaw

Rozporządzenie Ministra Infrastruktury i Budownictwa z dnia 23 grudnia 2015 r. w sprawie zakresu informacji o wynikach zleconych badań próbek,

3 przeprowadzonych kontrolach wyrobów budowlanych wprowadzonych do obrotu lub udostępnianych na rynku krajowym i wydanych postanowieniach, decyzjach i opiniach oraz sposobu i terminu przekazywania tych informacji

Rozporządzenie Ministra Infrastruktury i Budownictwa z dnia 23 grudnia

42015 r. w sprawie próbek wyrobów budowlanych wprowadzonych do obrotu lub udostępnianych na rynku krajowym

Rozporządzenie Ministra Infrastruktury i Budownictwa z dnia 23 grudnia

52015 r. w sprawie sposobu prowadzenia Krajowego Wykazu Zakwestionowanych Wyrobów Budowlanych

Rozporządzenie Prezesa Rady Ministrów z dnia 28 grudnia 2015 r. w spra-

6 wie średniego kursu złotego w stosunku do euro stanowiącego podstawę przeliczania wartości zamówień publicznych

Rozporządzenie Prezesa Rady Ministrów z dnia 28 grudnia 2015 r. w spra-

7 wie kwot wartości zamówień oraz konkursów, od których jest uzależniony obowiązek przekazywania ogłoszeń Urzędowi Publikacji Unii Europejskiej

Rozporządzenie Ministra Rozwoju z dnia 29 stycznia 2016 r. w sprawie ro-

8 dzajów i ilości znajdujących się w zakładzie substancji niebezpiecznych, decydujących o zaliczeniu zakładu do zakładu o zwiększonym lub dużym ryzyku wystąpienia poważnej awarii przemysłowej

Rozporządzenie Ministra Rozwoju z dnia 29 stycznia 2016 r. w sprawie warunków obniżania wartości korekt finansowych oraz wydatków poniesionych nieprawidłowo związanych z udzielaniem zamówień

Rozporządzenie Ministra Obrony Narodowej z dnia 13 listopada 2015 r. zmieniajace rozporzadzenie w sprawie warunków technicznych, jakim powinny odpowiadać obiekty budowlane niebędące budynkami, służące obronności Państwa oraz ich usytuowanie

Rozporządzenie Ministra Obrony Narodowej z dnia 13 listopada 2015 r.

11 zmieniające rozporządzenie w sprawie warunków technicznych, jakim powinny odpowiadać strzelnice garnizonowe oraz ich usytuowanie

Ustawa z dnia 13 kwietnia 2016 r. o systemach oceny zgodności i nadzoru rynku przedprojektowy

wymagania prawne i administracyjne

projektowanie

wymagania prawne i administracyjne

roboty budowlane

wymagania techniczne

roboty budowlane

wymagania techniczne

roboty

budowlane

wymagania techniczne

kontraktowanie

wymagania prawne i administracyjne

kontraktowanie

wymagania prawne $i$ administracyjne

przedprojektowy (studium wykonalności) wymagania prawne i administracyjne

przedprojektowy (studium

wykonalności); roboty budowlane (rozliczenie inwestycji)

projektowanie

projektowanie

roboty budowlane wymagania techniczne

wymagania techniczne

wymagania prawne i administracyjne

wymagania techniczne 
Lp.

Akt prawny

Legal regulation

$\begin{array}{lc}\text { Etap procesu } & \\ \text { inwestycyjnego } & \text { Obszar wpływu } \\ \text { Stage of the } & \text { Area of influence } \\ \text { investment process } & \end{array}$

Rozporzadzenie Ministra Infrastruktury i Budownictwa z dnia 20 kwietnia 2016 r. w sprawie zmiany rozporządzenia zmieniającego rozporządzenie w sprawie wymagań w zakresie odległości i warunków dopuszczających 13 usytuowanie drzew i krzewów, elementów ochrony akustycznej i wykonywania robót ziemnych w sąsiedztwie linii kolejowej, a także sposobu urządzania i utrzymywania zasłon odśnieżnych oraz pasów przeciwpożarowych

14 Rozporządzenie Ministra Rozwoju z dnia 3 czerwca 2016 r. w sprawie wymagań dla dźwigów i elementów bezpieczeństwa do dźwigów

15 Ustawa z dnia 20 maja 2016 r. o efektywności energetycznej

16 Ustawa $\mathrm{z}$ dnia 9 czerwca $2016 \mathrm{r}$. o zmianie ustawy o wspieraniu rozwoju usług i sieci telekomunikacyjnych oraz niektórych innych ustaw

17 Ustawa z dnia 20 maja 2016 r. o inwestycjach w zakresie elektrowni wiatrowych

18 Ustawa z dnia 22 czerwca 2016 r. o zmianie ustawy - Prawo zamówień publicznych oraz niektórych innych ustaw

Rozporządzenie Ministra Infrastruktury i Budownictwa z dnia 1 lipca 2016 r. w sprawie zakresu projektu miejscowego planu rewitalizacji w części tekstowej oraz zakresu i formy wizualizacji ustaleń miejscowego planu rewitalizacji

Rozporządzenie Ministra Środowiska z dnia 25 sierpnia 2016 r. w sprawie opłat za usunięcie drzew i krzewów

21 Ustawa z dnia 22 lipca 2016 r. o zmianie ustawy - Prawo energetyczne oraz niektórych innych ustaw

Ustawa z dnia 22 lipca 2016 r. o zmianie ustawy o minimalnym wynagrodzeniu za pracę oraz niektórych innych ustaw

Rozporządzenie Ministra Rozwoju z dnia 22 sierpnia 2016 r. zmieniające rozporządzenie w sprawie kwot wartości zamówień oraz konkursów, od których jest uzależniony obowiązek przekazywania ogłoszeń Urzędowi Publikacji Unii Europejskiej

Rozporządzenie Ministra Infrastruktury i Budownictwa z dnia 24 sierpnia 2016 r. w sprawie wzorów: wniosku o pozwolenie na budowę lub rozbiórkę, zgłoszenia budowy i przebudowy budynku mieszkalnego jednorodzinnego, oświadczenia o posiadanym prawie do dysponowania nieruchomością na cele budowlane, oraz decyzji o pozwoleniu na budowę lub rozbiórkę

Ustawa z dnia 21 lipca 2016 r. o zmianie ustawy o szczególnych zasadach

25 przygotowania i realizacji inwestycji w zakresie lotnisk użytku publicznego

investment process $\begin{array}{ll}\text { projektowanie } & \text { wymagania } \\ \text { techniczne }\end{array}$

projektowanie

wymagania techniczne

przedprojektowy

wymagania prawne i administracyjne

projektowanie roboty budowlane

projektowanie roboty budowlane

wymagania prawne i administracyjne

wymagania prawne

kontraktowanie

wymagania prawne i administracyjne

projektowanie

wymagania techniczne

roboty

budowlane

projektowanie

roboty

budowlane

kontraktowanie

wymagania prawne $i$ administracyjne

projektowanie (pozwolenie na budowę lub rozbiórkę)

wymagania prawne $i$ administracyjne

projektowanie roboty budowlane i administracyjne wymagania prawne $i$ administracyjne 


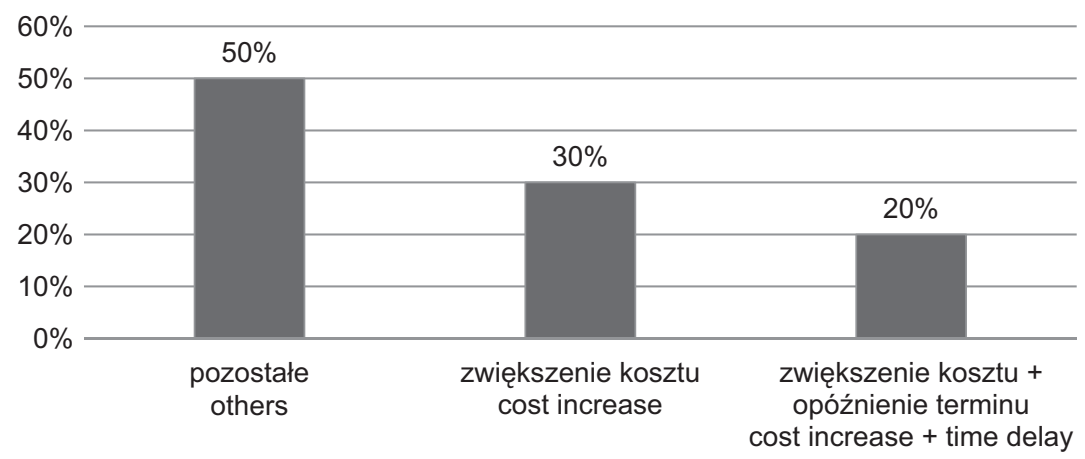

Rys. 2. Wpływ zmian przepisów prawa na realizację budowlanego procesu inwestycyjnego

Fig. 2. The impact of alternations of legal regulations on the execution of the construction investment process

Bez względu na rangę zmian w prawie należy mieć świadomość, że mogą one wystapić i spowodować utrudnienie w realizowaniu inwestycji według założonego planu. W związu z tym konieczne jest ciagge monitorowanie zakłóceń generowanych przez zmiany przepisów prawa oraz badanie wrażliwości uczestników procesu budowlanego na ich skutki.

\section{PODSUMOWANIE}

Warunkiem prawidłowego przebiegu i zakończenia inwestycji budowlanej jest wiedza z zakresu warunków technicznych wykonania obiektów budowlanych oraz znajomość aktualnego stanu prawnego. W ostatnich latach wprowadzono wiele zmian w przepisach prawnych. Przeprowadzona analiza wykazała, że dotyczyły one głównie uwarunkowań prawnych i administracyjnych budowlanego procesu inwestycyjnego. Należy przyjąć, że w każdym roku mogą one dotyczyć innych obszarów działalności budowlanej.

Zmiany istniejących bądź wprowadzenie nowych regulacji prawnych mogą spowodować zakłócenia w przebiegu procesu budowlanego. Mogą m.in. mieć wpływ na koszt i czas realizacji inwestycji. W związku z tym zalecana jest ocena i monitorowanie ryzyka prawnego we wszystkich fazach procesu inwestycyjnego w celu zminimalizowania skutków negatywnego jego wpływu na projekt.

Przedstawiona $\mathrm{w}$ pracy analiza może być przydatna w opracowywaniu zagadnień związanych z ryzykiem procesów budowlanych oraz w przygotowywaniu procedur, ocen i decyzji dotyczących inwestycji.

\section{PIŚMIENNICTWO}

Bizon-Górecka, J. i Górecki, J. (2015). Ryzyko projektu inwestycyjno-budowlanego w perspektywie formuły jego realizacji. Studies \& Proceedings of Polish Association for Knowledge Management, 74, 4-15.

Błachut, K., Rybka, I., Rybka, J. i Sługocki, M. (2013). Zamówienia publiczne - ścieżki postępowania. Wrocław: Grupa Wydawnicza Marciszewski.

Dziennik Ustaw (2016). Pobrano z lokalizacji: http://www.dziennikustaw.gov.pl/.

Głuszak, M. i Leśniak, A. (2015). Czynniki powodujące opóźnienia budowy - wielowymiarowa analiza statystyczna. W S. Bielniak (red.), Zastosowanie metod matematycznych w wybranych problemach zarzadzania $w$ budownictwie. (strony 79-105). Kraków: Politechnika Krakowska.

Grant Thornton (2016). Barometr stabilności otoczenia prawnego w Polsce. Pobrano z lokalizacji: http://barometrprawa.pl/. Internetowy System Aktów Prawnych [ISAP] (2016). Pobrano z lokalizacji: http://isap.sejm.gov.pl/.

Korycki, S., Kuciński, J. i Trzciński, Z. (2007). Zarys prawa. Warszawa: Wydawnictwo Prawnicze „LexisNexis”. 
Kuziak, K. (2008). Zarządzanie ryzykiem prawnym w przedsiębiorstwie. Prace Naukowe Akademii Ekonomicznej we Wroctawiu. Finanse, Bankowość, Rachunkowość, 6, 1196, 91-99.

Olszewski, A. (2011). Rozwiązywanie sporów z umów o roboty budowlane zawartych w zamówieniach publicznych. Inżynier Budownictwa, 01(80), 21-25.

Ostrowska, E. (2002). Ryzyko projektów inwestycyjnych. Warszawa: Polskie Wydawnictwo Ekonomiczne.

\title{
THE INFLUENCE OF ALTERNATIONS IN LEGAL REGULATIONS ON COMPLETION OF CONSTRUCTION INVESTMENT PROCESS
}

\begin{abstract}
The study presents the issue of alternations in legal regulations with regard to the construction investment process. Changes, implemented in recent years, apply to all stages and areas of construction investment process, especially legal and administrative area. They can contribute to impediments in activities of all participants of a construction project. Conducted research indicates that cost increase of the investment may be a consequence of alternated regulations. Due to random nature of such events risk management of alternations in legal regulations is necessary in the construction process.
\end{abstract}

Key words: legal regulations, construction investment process, risk 